\title{
PERANCANGAN INVERTER SATU FASA OFF-GRID MENGGUNAKAN DSPIC30F4011 DENGAN KONTROL ARUS METODE PROPORTIONAL RESONANT
}

\author{
Segal Mancini Suroso *), Iwan Setiawan dan Bambang Winardi \\ Departemen Teknik Elektro, Universitas Diponegoro \\ Jl. Prof. Sudharto, SH, Kampus UNDIP Tembalang, Semarang 50275, Indonesia \\ *)E-mail: segalmancini@gmail.com
}

\begin{abstract}
Abstrak
Ketersediaan bahan bakar fosil sebagai bahan bakar pada pembangkit listrik konvensional semakin menipis. Hal ini menyebabkan penggunaan energi baru terbarukan seperti teknologi photovoltaic (PV) menjadi sangat penting. Dalam penggunaan sistem PV diperlukan inverter yang berguna untuk mengkonversi tegangan DC menjadi tegangan AC, dimana kualitas arus keluaran inverter sangat berpengaruh pada kualitas daya. Oleh karena itu, perlu adanya pengontrolan arus keluaran inverter yang berfungsi untuk memperbaiki respon sistem dan meminimalisir harmonisa arus yang terjadi. Dalam penelitian ini, dirancang Inverter Satu Fasa tipe H-Bridge menggunakan mikrokontroler 16-bit DSPIC30F4011 dengan kontrol arus metode proportional resonant. Arus keluaran inverter diumpan-balikkan oleh sensor arus ACS71205B. Pengujian dilakukan dengan rentang arus referensi sebesar $1-3$ A pada variasi beban $7 \Omega$ dan $12 \Omega$. Hasil pengujian menunjukkan gelombang arus aktual keluaran inverter dapat mengikuti perubahan arus referensi yang diberikan dengan baik. Nilai induktor yang kurang sesuai dan efek pensaklaran menyebabkan masih adanya ripple yang terjadi. Semakin tinggi tegangan keluaran pada inverter akan menghasilkan distorsi harmonisa arus total menjadi semakin kecil.
\end{abstract}

Kata kunci : Kontrol Arus, Proportional Resonant, Inverter, DSPIC30F4011

\begin{abstract}
The availability of fossil as fuel in conventional power plants is running low. This causes the use of renewable energy such as photovoltaic (PV) technology becomes very important. PV systems required inverters for converting DC voltage into AC voltage, where the quality of the inverter output current is very influential on the quality of power. Therefore, it is necessary to control the inverter current output which serves to improve the system response and minimize the current harmonics. In this research, a H-Bridge type of one phase Inverter is designed using 16-bit DSPIC30F4011 microcontroller with current control proportional resonant method. The inverter output current is fedback by the ACS71205B current sensor. The test is carried out with the reference current range of $1-3 \mathrm{~A}$ on the load variation $7 \Omega$ and $12 \Omega$. The test results show the actual current waveform of the inverter output is able to follow the reference current changes. Inductor value that not suitable and the effect of switching cause the ripple is still happening. The higher the output voltage of the inverter will result in the total current harmonic distortion becoming smaller.
\end{abstract}

\section{Keywords: Current Control, Proportional Resonant, Inverter, DSPIC30F4011}

\section{Pendahuluan}

Penggunaan sumber daya terbarukan pada pembangkit listrik menjadi semakin penting. Hal ini dikarenakan kebutuhan energi listrik dari hari ke hari semakin tinggi dan ketersediaan bahan bakar fosil sebagai bahan bakar utama pada pembangkit listrik konvensional semakin terbatas [1]. Salah satu penggunaan energi baru terbarukan sebagai pembangkit listrik adalah teknologi photovoltaic (PV). Teknologi PV semakin berkembang karena adanya dukungan dari pemerintah dan beberapa perusahaan untuk menyambungkan PV dengan grid [2]. Oleh karena itu diperlukan perangkat inverter sebagai pengkonversi tegangan DC menjadi tegangan AC. Kualitas arus keluaran inverter sangat berpengaruh pada kualitas daya. Sehingga perlu adanya pengontrolan arus keluaran inverter yang berfungsi untuk memperbaiki respon sistem dan meminimalisir harmonisa arus yang terjadi [3].

Penelitian tentang implementasi kontrol arus pada inverter yang dilakukan [4] menggunakan mikrokontroler 16-bit dsPIC30f401 menunjukan bahwa metode Proportional Resonant lebih presisi dibandingkan metode Proportional 
Integral. Pada penelitian [5] menggunakan mikrokontroler 16-bit dsPIC30f401 menunjukan bahwa metode Proportional Resonant lebih presisi dibandingkan metode Proportional dan PWM Open Loop.

Penelitian ini merancang inverter satu fasa off-grid dengan teknik pemicuan SPWM berbasis microcontroller 16-bit dsPIC30f401 yang tersinkronisasi dengan grid. Pengendalian arus direalisasikan dengan menggunakan metode Proportional Resonant. Frekuensi kerja inverter diatur konstan sebesar $50 \mathrm{~Hz}$. Diharapkan tegangan dan arus keluaran inverter dapat memiliki respon yang cepat terhadap referensi yang diberikan dan perubahan beban, serta memiliki gelombang yang mendekati sinusoidal.

\section{Metode}

\subsection{Perancangan Hardware}

Perancangan inverter satu fasa tipe H-bridge dengan kontrol arus proportional resonant yang dilakukan pada penelitian ini terdiri dari beberapa blok utama, yaitu blok suplai AC 1 fasa, blok rangkaian daya, blok rangkaian kontrol, blok sensor arus ACS712-05B, blok modul Digital-to-Analog Converter AD7302, serta blok beban. Diagram blok perangkat keras yang dirancang pada penelitian ini ditunjukkan pada Gambar 1 .

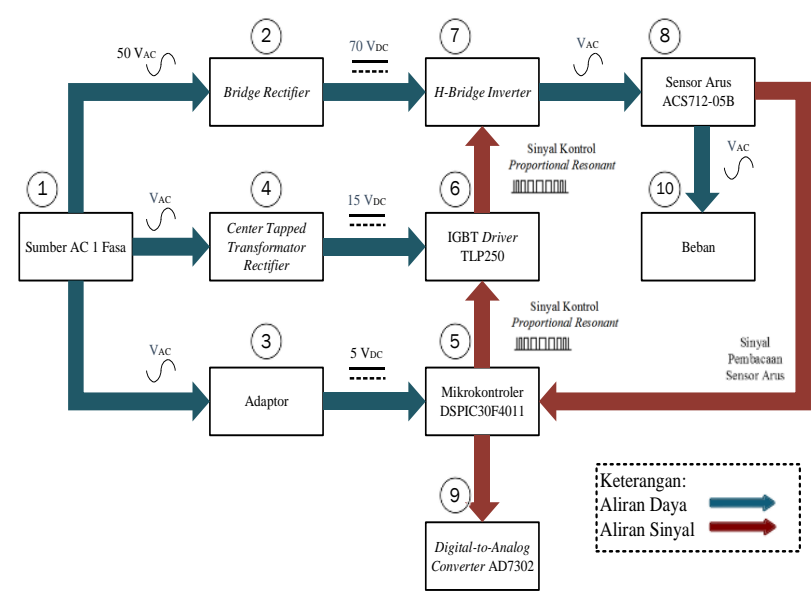

Gambar 1. Diagram Blok Perancangan Perangkat Keras

Spesifikasi inverter satu fasa tipe $H$-bridge berdasarkan Gambar 1. yang dirancang pada penelitian ini dijelaskan sebagai berikut :

1. Sumber tegangan AC 1 fasa digunakan untuk mensuplai rangkaian daya dan rangkaian kontrol.

2. Suplai tegangan DC untuk rangkaian daya inverter diperoleh dari hasil penyearahan tegangan $\mathrm{AC}$ menggunakan bridge rectifier.

3. Suplai mikrokontroler DSPIC30F4011 menggunakan Adaptor 5 V / 2 A

4. Suplai $15 \quad \mathrm{~V}_{\mathrm{DC}}$ untuk rangkaian driver IGBT diperoleh dari hasil penyearahan tegangan $\mathrm{AC}$ keluaran trafo menggunakan center-tapped full wave rectifier.

5. Mikrokontroler 16-Bit DSPIC30F4011 digunakan untuk menghasilkan sinyal kontrol proportional resonant berdasarkan arus aktual yang terukur oleh sensor dan arus referensi yang diberikan. Arus referensi dihasilkan melalui pembacaan potensiometer melalui fasilitas ADC.

6. TLP250 digunakan sebagai IGBT driver

7. Jenis inverter yang dirancang adalah inverter satu fasa tipe $H$ Bridge, yang terdiri dari empat buah IGBT tipe IRG4PC50UD

8. Sensor arus ACS712-05B digunakan untuk mengukur arus keluaran inverter dan mengirim informasi berupa tegangan kepada mikrokontroler DSPIC30F4011 melalui fasilitas ADC.

9. Digital-to-Analog Converter AD7302 digunakan untuk menampilkan tegangan keluaran yang merepresentasikan arus referensi dan arus aktual yang diukur oleh sensor pada osiloskop.

10. Blok beban terdiri dari beban yang terhubung dengan keluaran inverter satu fasa. Beban yang digunakan dalam perancangan penelitian ini adalah berupa resistor.

\subsubsection{IGBT Driver TLP250}

Rangkaian TLP 250 digunakan untuk mengisolasi dan menguatkan sinyal kontrol proportional resonant dengan level tegangan 5 Volt yang dibangkitkan dsPIC30f4011 menjadi level tegangan yang lebih tinggi dengan sistem ground terpisah (level tegangan $15 \mathrm{~V}$ ) dan cukup untuk memicu IGBT (Insulated Gate Bipolar Transistor) sebagai driver [6].

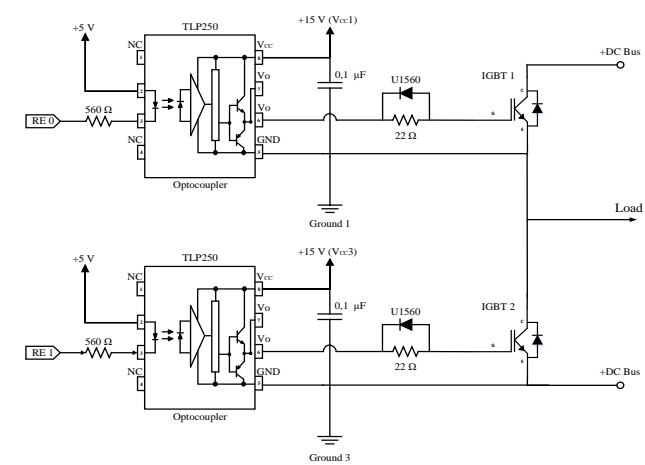

Gambar 2. Rangkaian MOSFET Driver TLP250

IGBT driver pada sisi high menggunakan suplai pemicuan dengan ground terpisah dengan fasa lain dan sisi low. Hal ini dikarenakan ground yang dijadikan referensi untuk pemicuan sisi high masing-masing fasa berbeda, sehingga digunakan dua buah sumber DC yang terpisah secara listrik. Sedangkan IGBT driver pada sisi low, ground yang dijadikan titik referensi sama, sehingga hanya diperlukan satu buah sumber DC yang terpisah secara listrik dari sumber DC untuk pemicuan pada pada sisi high. 


\subsubsection{Sensor Arus ACS712-05B}

Sensor arus ACS712-05B digunakan sebagai perangkat pengukuran dan pembacaan nilai arus aktual yang melalui beban dalam perancangan penelitian ini. Sensor ini bekerja dengan prinsip hall effect. Arus yang mengalir melewati sensor akan dibaca dan dikonversikan menjadi nilai tegangan yang proporsional, kemudian sinyal berupa tegangan tersebut akan dibaca oleh modul ADC pada mikrokontroler DSPIC30F4011.

Tegangan keluaran sensor akan bernilai sekitar 2,5 V saat tidak ada arus yang mengalir melewati sensor. Berdasarkan datasheet, sensitivitas sensor arus ACS712-05B ini adalah sebesar $185 \mathrm{mV} / \mathrm{A}$ [7], namun jenis sensor yang digunakan sudah dilengkapi IC op-amp atau penguat sinyal TLC2272ACD yang dapat digunakan untuk mengatur nilai offset dan gain melalui dua potensiometer yang dihubungkan pada IC op-amp tersebut. Potensiometer gain diatur hingga nilai sensitivitas sensor berubah menjadi 0,5 V/A, sehingga nilai tegangan keluaran maksimal dari sensor saat arus yang terbaca sebesar 5 A sesuai dengan Persamaan 1 berikut.

$V_{\text {out }}=2,5+0,5 \cdot i$

$V_{\text {out }}=2,5+0,5 \cdot 5$

$V_{\text {out }}=5 \mathrm{~V}$

Tegangan keluaran sensor diatur menjadi maksimal $5 \mathrm{~V}$ untuk memudahkan pembacaan oleh modul analog-todigital converter yang memiliki tegangan referensi sebesar $5 \mathrm{~V}$.

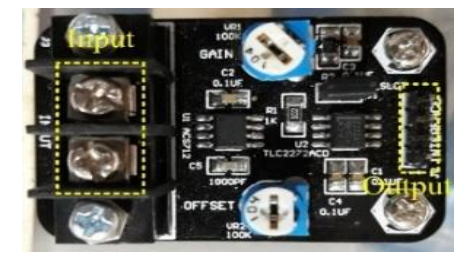

Gambar 3. Sensor Arus ACS712-05B

\subsubsection{Inverter Satu Fasa Tipe H-Bridge}

Inverter satu fasa yang dirancang menggunakan topologi $\mathrm{H}$-bridge. Topologi ini terdiri atas dua leg dimana pada masing-masing leg terdapat dua buah IGBT sebagai komponen pensaklaran, sehingga terdapat empat buah IGBT dalam rangkaian inverter. IGBT yang digunakan adalah tipe IRG4PC50UD.

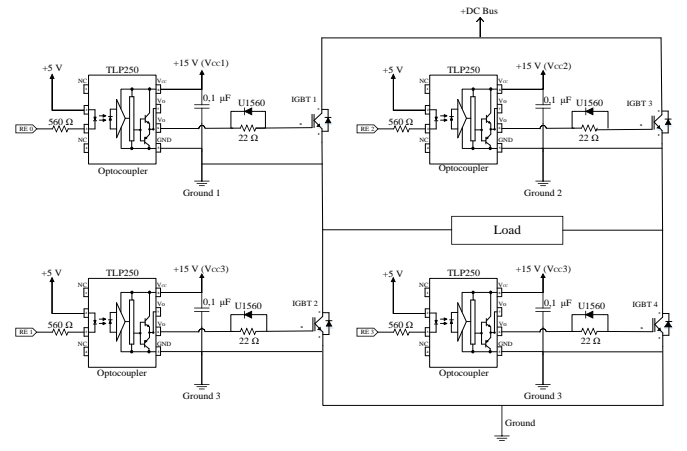

Gambar 4. Rangkaian Inverter Satu Fasa Tipe H Bridge

IGBT sisi atas (high-side) terhubung dengan driver yang memiliki suplai DC terpisah dengan fasa lain dan IGBT driver sisi low, sedangkan IGBT pada sisi bawah (lowside) terhubung dengan rangkaian driver yang memiliki titik referensi ground yang sama dengan IGBT driver sisi low pada fasa yang lain [8].

\subsection{Kontrol Arus Proportional Resonant pada Inverter Satu Fasa}

Sinyal kontrol proportional resonant digunakan untuk mengumpan balikkan nilai keluaran arus dari inverter dengan mengontrol variabel sinusoidal yang memiliki frekuensi resonansi di $50 \mathrm{~Hz}$. Nilai error $e(t)$ diperoleh dari hasil pengurangan nilai arus aktual yang diukur oleh sensor arus $(y)$ dan nilai referensi arus yang diberikan lewat potensiometer $(u)$. Setelah nilai $e(t)$ didapatkan, kontroler akan menghitung nilai error dengan nilai penguatan untuk menghasilkan sinyal kontrol [9].

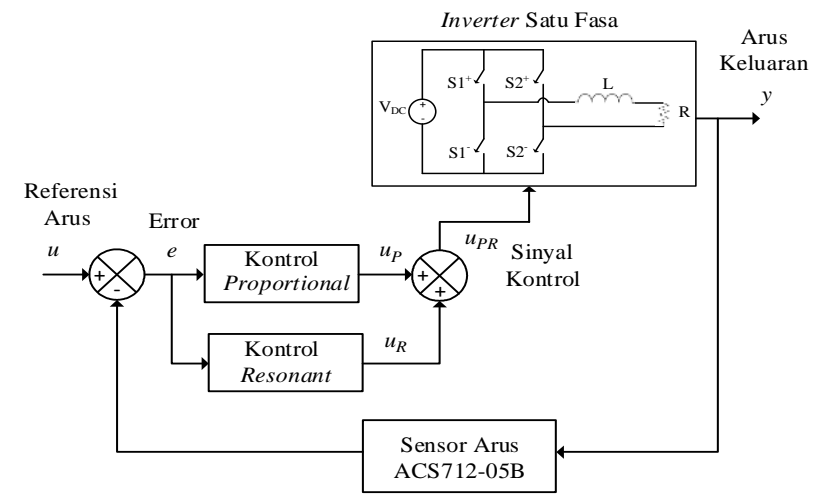

Gambar 5. Diagram Blok Kontroler Proportional Resonant

Berikut adalah persamaan kontroler Proportional Resonant dalam bentuk transformasi Laplace [10]:

$G_{P R}(s)=K_{p}+\frac{2 K_{r} \omega_{P R c} s}{s^{2}+2 \omega_{P R C} s+\omega_{1}^{2}}$ 
Fungsi alih dalam domain s harus didiskritisasi menjadi domain k agar dapat diolah dalam mikrokontroler. Dengan metode pendekatan Backward Difference yang ditunjukkan dalam persamaan (3) [11]:

$s=\frac{1-z^{-1}}{T}$

Berikut ini adalah nilai parameter kontroler proportional yang dilakukan dengan metode empiris:

- $K_{p}=0,9$

Didapat persamaan kontroler proportional sebagai berikut:

$u_{P}(k)=K p \cdot e(k)$

$u_{P}(k)=0,9 \cdot e(k)$

Persamaan yang didiskritisasi adalah gain resonant karena memiliki sistem orde dua dalam fungsi alih domain s.

$\frac{u_{R}(s)}{e(s)}=\frac{2 K r \omega_{P R} s}{s^{2}+2 \omega_{P R} s+\omega^{2}}$

$u_{R}(z)$

$=\left(\frac{1}{1+2 \omega_{P R} T+\omega^{2} T^{2}}\right)\left(-u(z) \cdot z^{-2}\right.$

$+u(z) \cdot z^{-1}\left(2+2 \omega_{P R} T\right)-e(z) \cdot z^{-1}\left(2 K r \omega_{P R} T\right)$

$\left.+e(z)\left(2 K r \omega_{P R} T\right)\right)$

$u_{R}(k)$

$=-\frac{u(k-2)}{1+2 \omega_{P R} T+\omega^{2} T^{2}}+\frac{\left(2+2 \omega_{P R} T\right) \cdot u(k-1)}{1+2 \omega_{P R} T+\omega^{2} T^{2}}$

$-\frac{2 K r \omega_{P R} T \cdot e(k-1)}{1+2 \omega_{P R} T+\omega^{2} T^{2}}$

$+\frac{2 K r \omega_{P R} T \cdot e(k)}{1+2 \omega_{P R} T+\omega^{2} T^{2}}$

Berikut ini adalah nilai parameter kontroler resonant yang dilakukan dengan metode empiris:

- $K_{r}=7135,69$

- $\omega_{P R c}=0,07$

- $\omega_{1}=314$

- $T=0,0001$

Berdasarkan persamaan (7) didapat persamaan kontroler resonant sebagai berikut:

$$
\begin{aligned}
u_{R}(k)= & -0,999 \cdot u(k-2)+1,998 \cdot u(k-1)- \\
& 0,09998 \cdot e(k-1)+0,09998 \cdot e(k)
\end{aligned}
$$

Setelah itu didapatkan persamaan akhir dari kontroler Proportional Resonant sebagai berikut:

$$
\begin{aligned}
u_{P R}(k)= & u_{P}(k)+u_{R}(k) \\
u_{P R}(k)= & 0,9 \cdot e(k)-0,999 \cdot u(k-2)+1,998 \cdot u(k-1) \\
& -0,09998 \cdot e(k-1)+0,09998 \cdot e(k)
\end{aligned}
$$

\section{Hasil dan Analisa \\ 3.1. Pengujian Gelombang Keluaran DSPIC30F4011}

Pengujian dilakukan untuk memastikan bahwa modul PWM pada DSPIC30F4011 dapat membangkitkan sinyal kontrol dalam mode komplementer dengan adanya dead time sebesar $2 \mathrm{uS}$ antara pin PWMxL dan PWMxL. Pengujian dilakukan dengan program PWM open loop dengan frekuensi PWM $20 \mathrm{kHz}$.

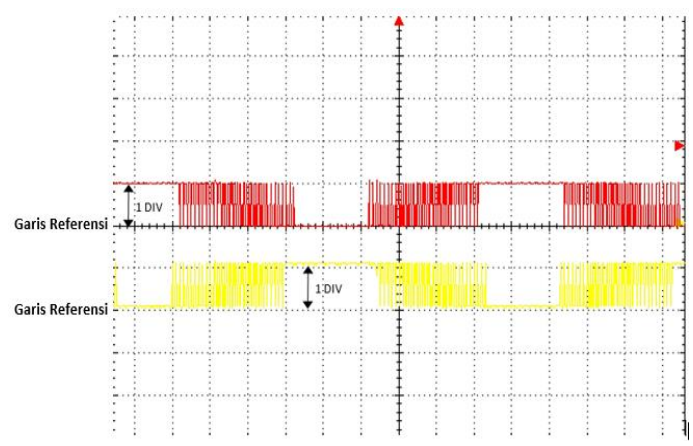

Gambar 6. Gelombang Keluaran SPWM Open Loop

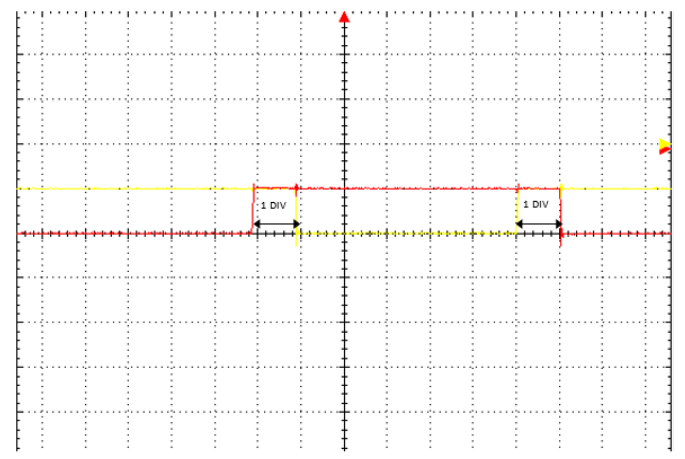

Gambar 7. Dead Time pada Keluaran SPWM Open Loop

Hasil pengujian keluaran DSPIC30F4011 pada SPWM open loop menunjukkan bahwa sinyal kontrol bekerja dalam mode komplementer serta adanya dead time sebesar $2 \mathrm{uS}$ antara PWM sisi high dan PWM sisi low.

\subsection{Pengujian Gelombang Keluaran IGBT Driver TLP250}

Pengujian pada rangkaian ini dilakukan untuk mengetahui dan memastikan gelombang tegangan keluaran dari IGBT driver TLP250 telah sesuai dengan perancangan dan dapat digunakan untuk pemicuan IGBT. 


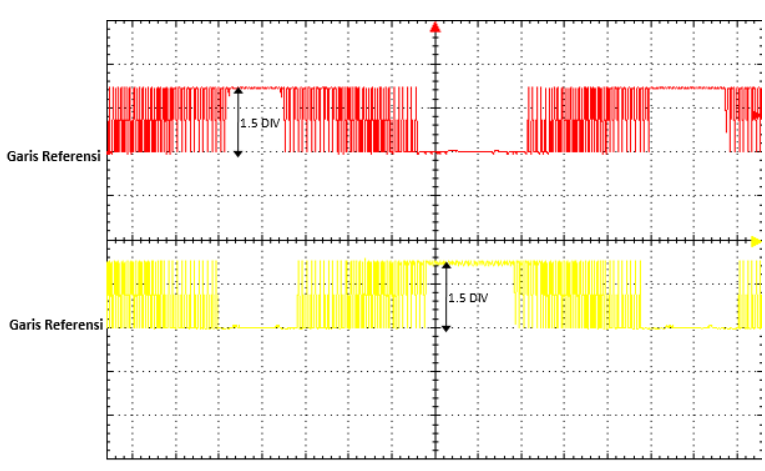

Gambar 8. Gelombang Keluaran Driver IGBT TLP250

Hasil pengujian gelombang keluaran dari IGBT driver TLP250 telah sesuai dengan perancangan dan dapat digunakan untuk memicu IGBT.

\subsection{Pengujian Sensor Arus ACS712-05B}

Pengujian Sensor Arus ACS712-05B bertujuan untuk mengetahui apakah keluaran sensor sudah sesuai dengan nilai offset dan sensitivitas pembacaan arus yang sudah diatur sebelumnya. Nilai offset tegangan keluaran sensor adalah 2,5 $\mathrm{V}$ dan sensitivitas pembacaan arus oleh sensor adalah 0,5 V/A. Pengujian ini dilakukan dengan mengukur tegangan keluaran sensor yang telah dikalibrasi sebelumnya saat dialiri arus sebesar $1 \mathrm{~A}$.

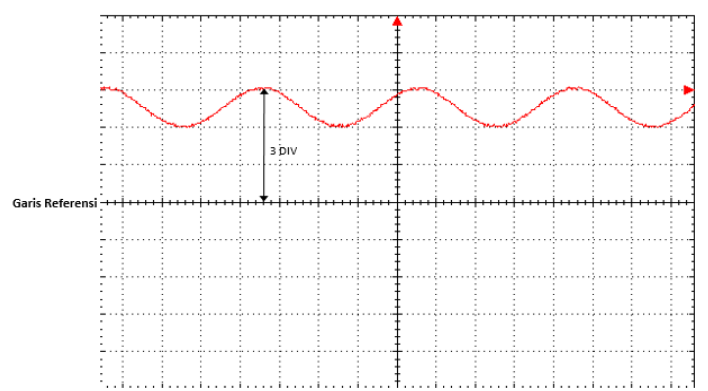

Gambar 9. Gelombang Keluaran Sensor Arus ACS712-05B $(\mathbf{I}=\mathbf{1}$ A)

Nilai tegangan puncak ke puncak pada pengujian sensor dalam Gambar 9 memiliki jumlah div 3 dengan skala V/div $=1 \mathrm{~V}$ dengan faktor pengali probe $1 \mathrm{x}$. Hal ini sudah sesuai dengan perancangan dimana saat arus $=1 \mathrm{~A}$ maka diperoleh tegangan keluaran sensor sebagai berikut:

$V_{\text {out }}=2,5+0,5 \cdot i$

$V_{\text {out }}=2,5+0,5 \cdot 1$

$V_{\text {out }}=3 \mathrm{~V}$

\subsection{Pengujian Keluaran Inverter Satu Fasa dengan Kontrol Arus Proportional Integral}

Pengujian bertujuan untuk mengamati perbandingan arus referensi dan arus aktual pada keluaran inverter satu fasa yang dipicu oleh sinyal kontrol proportional integral. Arus referensi yang diberikan adalah 2 A dengan variasi beban $7 \Omega$ dan $12 \Omega$. Keluaran inverter diumpan-balikkan pada mikrokontroler DSPIC30F4011.

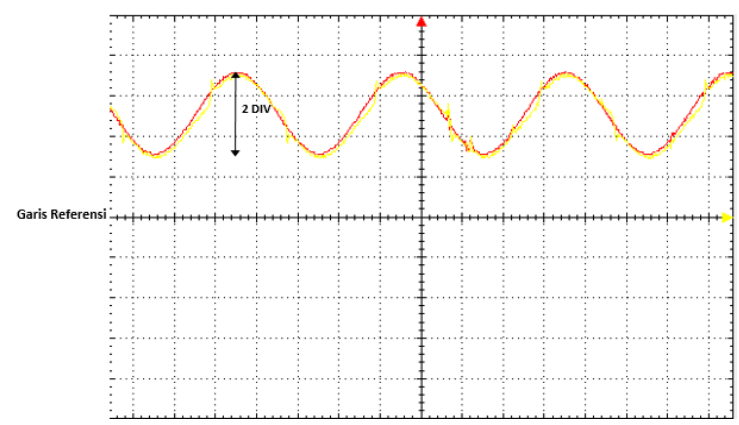

Gambar 10. Arus Keluaran Inverter Proportional Integral dengan Beban $7 \Omega$ pada Referensi 2 A

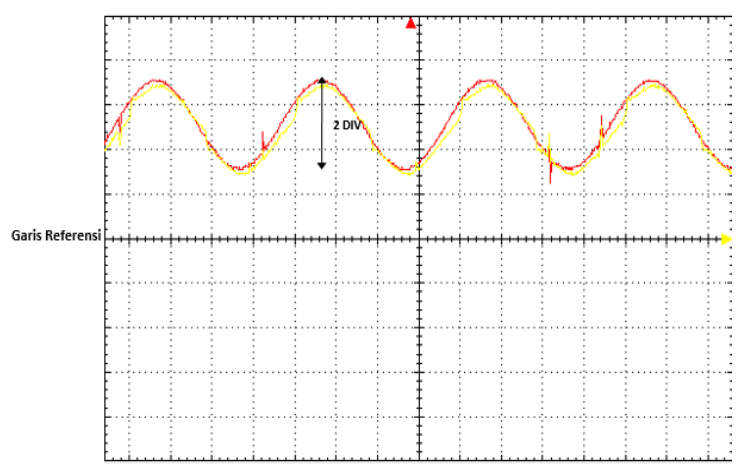

Gambar 11. Arus Keluaran Inverter Proportional Integral dengan Beban $12 \Omega$ pada Referensi 2 A

Berdasarkan hasil pengujian pada Gambar 10 dan Gambar 11 diperoleh bentuk gelombang keluaran perbandingan arus referensi $2 \mathrm{~A}$ (merah) dengan arus aktual (kuning) sebesar 2 div. Dapat dilihat bahwa arus aktual keluaran inverter sudah dapat mengikuti referensi yang diberikan. Nilai arus rms yang terukur pada beban $7 \Omega$ sebesar $2,2 \mathrm{~A}$, sedangkan nilai arus rms pada beban $12 \Omega$ sebesar $2,15 \mathrm{~A}$. Sehingga nilai arus rms yang terukur pada kedua beban sudah mendekati arus referensi yang dibangkitkan. Selisih antara arus referensi dan aktual dikarenakan adanya ripple yang disebabkan oleh efek switching yang dikontrol oleh kontroler proportional integral dan kurang sesuainya nilai induktor yang digunakan.

\subsection{Pengujian Keluaran Inverter Satu Fasa dengan Kontrol Arus Proportional Resonant}

Pengujian bertujuan untuk mengamati perbandingan arus referensi dan arus aktual pada keluaran inverter satu fasa yang dipicu oleh sinyal kontrol proportional resonant. Arus referensi yang diberikan adalah 2 A dengan variasi 
beban $7 \Omega$ dan $12 \Omega$. Keluaran inverter diumpan-balikkan pada mikrokontroler DSPIC30F4011.

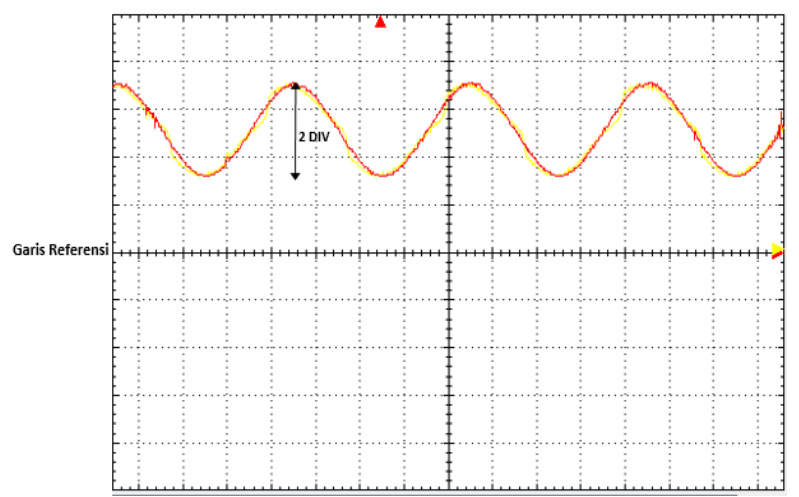

Gambar 12. Arus Keluaran Inverter Proportional Resonant dengan Beban $7 \Omega$ pada Referensi 2 A

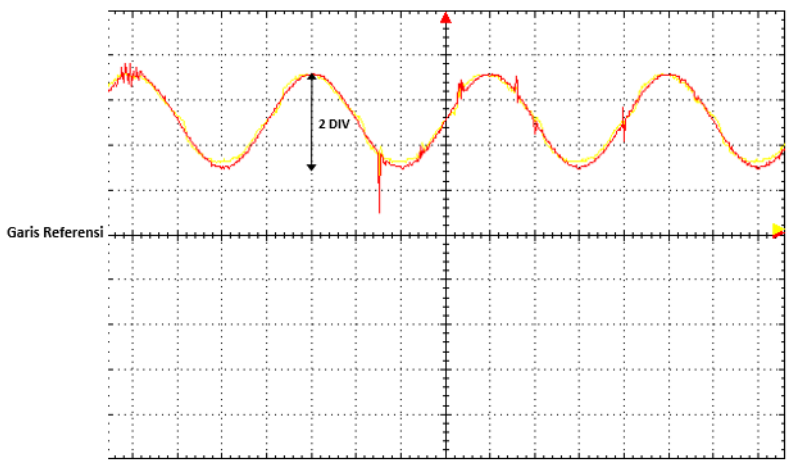

Gambar 13. Arus Keluaran Inverter Proportional Resonant dengan Beban $12 \Omega$ pada Referensi $2 \mathrm{~A}$

Berdasarkan hasil pengujian pada Gambar 12 dan Gambar 13 diperoleh bentuk gelombang keluaran perbandingan arus referensi $2 \mathrm{~A}$ (merah) dengan arus aktual (kuning) sebesar 2 div. Dapat dilihat bahwa arus aktual keluaran inverter sudah dapat mengikuti referensi yang diberikan. Nilai arus rms yang terukur pada beban $7 \Omega$ sebesar $2,09 \mathrm{~A}$, sedangkan nilai arus rms pada beban $12 \Omega$ sebesar $2,21 \mathrm{~A}$. Sehingga nilai arus rms yang terukur pada kedua beban sudah mendekati arus referensi yang dibangkitkan. Adanya selisih antara arus referensi dan aktual dikarenakan adanya ripple yang disebabkan oleh efek switching yang dikontrol oleh kontroler proportional resonant dan kurang sesuainya nilai induktor yang digunakan.

\subsection{Pengujian Keluaran Inverter Satu Fasa dengan Kontrol Arus Proportional Resonant Metode On-Grid}

Pengujian bertujuan untuk mengamati perbandingan arus referensi dan arus aktual pada keluaran inverter satu fasa yang dipicu oleh sinyal kontrol proportional resonant metode on-grid. Arus referensi yang diberikan adalah 2 A dengan variasi beban $7 \Omega$ dan $12 \Omega$. Keluaran inverter diumpan-balikkan pada mikrokontroler DSPIC30F4011.

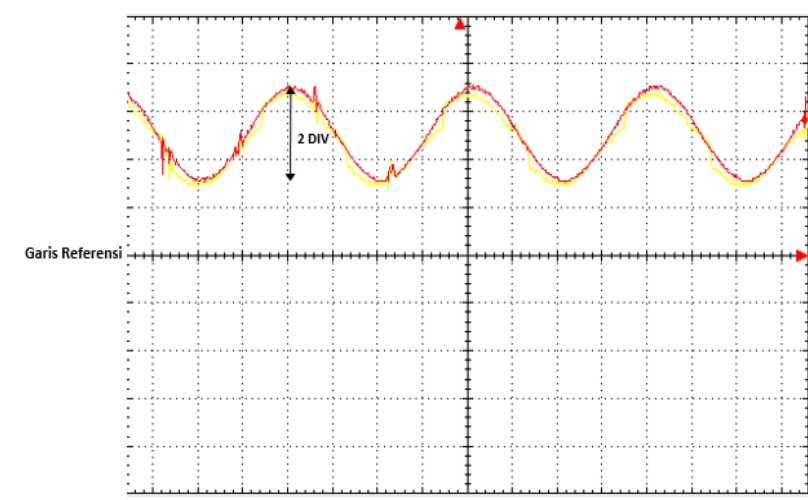

Gambar 14. Arus Keluaran Inverter Proportional Resonant Metode On-Grid dengan Beban $7 \Omega$ pada Referensi 2 A

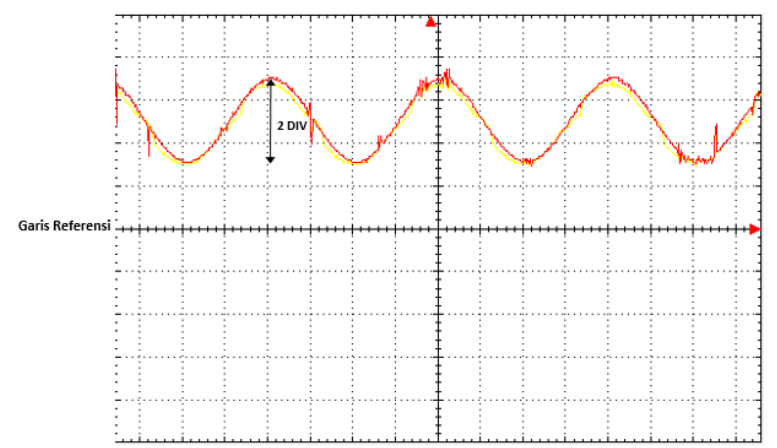

Gambar 15. Arus Keluaran Inverter Proportional Resonant Metode On-Grid dengan Beban $12 \Omega$ pada Referensi 2 A

Berdasarkan hasil pengujian pada Gambar 14 dan Gambar 15 diperoleh bentuk gelombang keluaran perbandingan arus referensi $2 \mathrm{~A}$ (merah) dengan arus aktual (kuning) sebesar 2 div. Dapat dilihat bahwa arus aktual keluaran inverter sudah dapat mengikuti referensi yang diberikan. Nilai arus rms yang terukur pada beban $7 \Omega$ sebesar 2,15 A, sedangkan nilai arus rms pada beban $12 \Omega$ sebesar 2,14 A. Sehingga nilai arus rms yang terukur pada kedua beban sudah mendekati arus referensi yang dibangkitkan. Adanya selisih antara arus referensi dan aktual dikarenakan adanya ripple yang disebabkan oleh efek switching yang dikontrol oleh kontroler proportional resonant metode on grid dan kurang sesuainya nilai induktor yang digunakan.

\subsection{Pengujian Distorsi Harmonisa Arus Total (THD-i)}

Pengujian THD-i bertujuan untuk mengetahui seberapa besar total distorsi periodik dari gelombang arus pada keluaran inveter yang telah dilengkapi dengan kontrol arus. Semakin besar nilai harmonisa yang terjadi maka semakin besar risiko kerusakan peralatan tersebut. 


\subsubsection{Pengujian Distorsi Harmonisa Arus Total (THD-i) pada Inverter dengan Kontrol Proportional Integral}

Berikut ini adalah hasil pengujian yang menunjukkan \% THD-i terhadap perubahan variasi beban dan arus referensi dengan kontrol proportional integral.

Tabel 1. Nilai \% THD-i Hasil Pengujian dengan Kontrol Proportional Integral

\begin{tabular}{ccc}
\hline $\begin{array}{c}\text { Arus Referensi } \\
(\mathrm{A})\end{array}$ & $\begin{array}{c}\text { \% THD-i } \\
\text { Beban 7 Ohm }\end{array}$ & $\begin{array}{c}\text { \% THD-i } \\
\text { Beban 12 Ohm }\end{array}$ \\
\hline 1 & 9,4 & 7,9 \\
1.5 & 9,6 & 8,2 \\
2 & 9,5 & 7,7 \\
2.5 & 9,3 & 7,9 \\
3 & 8,8 & 11,6 \\
\hline
\end{tabular}

Pada Tabel 1 dapat dilihat bahwa \%THD-i pada beban $7 \Omega$ lebih besar daripada \%THD-i pada beban $12 \Omega$. Dapat dilihat juga bahwa perubahan nilai arus referensi tidak berdampak banyak pada perubahan harmonisa yang terjadi. Namun terdapat penyimpangan pada saat menggunakan beban $12 \Omega$ dengan variasi arus referensi sebesar 3 A. Penyimpangan ini disebabkan arus aktual yang tidak dapat mengikuti arus referensi sebesar $3 \mathrm{~A}$ dengan baik pada variasi beban $12 \Omega$.

Berdasarkan SPLN D5.004 1: 2012 yang mengacu pada standar IEEE 519-1992, nilai maksimal \%THD-i yang diijinkan adalah 5\%. Hal ini menunjukkan bahwa nilai \%THD-i pada inverter dengan kontrol proportional integral yang telah diuji belum sesuai dengan standar yang berlaku. Tingginya \%THD-i yang terjadi disebabkan karena nilai filter yang digunakan kurang sesuai.

\subsubsection{Pengujian Distorsi Harmonisa Arus Total (THD-i) pada Inverter dengan Kontrol Proportional Resonant}

Berikut ini adalah hasil pengujian yang menunjukkan \%THD-i terhadap perubahan variasi beban dan arus referensi dengan kontrol proportional resonant.

Tabel 2. Nilai \% THD-i Hasil Pengujian dengan Kontrol Proportional Resonant

\begin{tabular}{ccc}
\hline $\begin{array}{c}\text { Arus Referensi } \\
(\mathrm{A})\end{array}$ & $\begin{array}{c}\text { \% THD-i } \\
\text { Beban 7 Ohm }\end{array}$ & $\begin{array}{c}\text { \% THD-i } \\
\text { Beban 12 Ohm }\end{array}$ \\
\hline 1 & 15,2 & 11,6 \\
1.5 & 13,7 & 10,5 \\
2 & 12,1 & 9,5 \\
2.5 & 11,7 & 9 \\
3 & 11,2 & 9,7 \\
\hline
\end{tabular}

Pada Tabel 2 dapat dilihat bahwa \%THD-i pada beban $7 \Omega$ lebih besar daripada \%THD-i pada beban $12 \Omega$. Dapat dilihat juga bahwa semakin besar arus referensi yang diberikan, maka nilai \%THD-i yang terjadi semakin kecil. Namun terdapat penyimpangan pada saat menggunakan beban $12 \Omega$ dengan variasi arus referensi sebesar 3 A. Penyimpangan ini disebabkan arus aktual yang tidak dapat mengikuti arus referensi sebesar 3 A dengan baik pada variasi beban $12 \Omega$

Berdasarkan SPLN D5.004 1: 2012 yang mengacu pada standar IEEE 519-1992, nilai maksimal \%THD-i yang diijinkan adalah $5 \%$. Hal ini menunjukkan bahwa nilai \% THD-i pada inverter dengan kontrol proportional resonant yang telah diuji belum sesuai dengan standar yang berlaku. Tingginya \%THD-i yang terjadi disebabkan karena nilai filter yang digunakan kurang sesuai.

\subsubsection{Pengujian Distorsi Harmonisa Arus Total (THD-i) pada Inverter dengan Kontrol Proportional Resonant On- Grid}

Berikut ini adalah hasil pengujian yang menunjukkan \% THD-i terhadap perubahan variasi beban dan arus referensi dengan kontrol proportional resonant metode ongrid.

Tabel 3. Nilai \% THD-i Hasil Pengujian dengan Kontrol Proportional Resonant Metode On-Grid

\begin{tabular}{ccc}
\hline $\begin{array}{c}\text { Arus Referensi } \\
\text { (A) }\end{array}$ & $\begin{array}{c}\text { \% THD-i } \\
\text { Beban 7 Ohm }\end{array}$ & $\begin{array}{c}\text { \% THD-i } \\
\text { Beban 12 Ohm }\end{array}$ \\
\hline 1 & 14,6 & 10,2 \\
1.5 & 12,8 & 9,9 \\
2 & 11,6 & 8,9 \\
2.5 & 10,8 & 8 \\
3 & 9,9 & 9,5 \\
\hline
\end{tabular}

Pada Tabel 3 dapat dilihat bahwa \%THD-i pada beban $7 \Omega$ lebih besar daripada \%THD-i pada beban $12 \Omega$. Dapat dilihat juga bahwa semakin besar arus referensi yang diberikan, maka nilai \%THD-i yang terjadi semakin kecil. Namun terdapat penyimpangan pada saat menggunakan beban $12 \Omega$ dengan variasi arus referensi sebesar 3 A. Penyimpangan ini disebabkan arus aktual yang tidak dapat mengikuti arus referensi sebesar 3 A dengan baik pada variasi beban $12 \Omega$

Berdasarkan SPLN D5.004 1: 2012 yang mengacu pada standar IEEE 519-1992, nilai maksimal \%THD-i yang diijinkan adalah $5 \%$. Hal ini menunjukkan bahwa nilai \%THD-i pada inverter dengan kontrol proportional resonant metode on-grid yang telah diuji belum sesuai dengan standar yang berlaku. Tingginya \%THD-i yang terjadi disebabkan karena nilai filter yang digunakan kurang sesuai nilai \%THD-i yang dihasilkan dengan 
menggunakan kontrol proportional resonant metode ongrid lebih kecil dibandingkan menggunakan kontrol proportional resonant yang belum dilengkapi dengan sinkronisasi tegangan grid PLN. Hal ini menunjukan bahwa kontrol proportional resonant metode on-grid adalah kontrol yang paling baik untuk digunakan sebagai pengendalian arus AC

\section{Kesimpulan}

Inverter satu fasa tipe $H$ Bridge dengan kontroler arus proportional resonant telah direalisasikan dan dapat menghasilkan tegangan keluaran AC satu fasa terkontrol, dengan arus referensi yang dapat diatur. Gelombang arus keluaran pada inverter dengan kontroler arus proportional resonant sudah dapat mengikuti referensi arus yang diberikan dengan baik. Adanya ripple pada tegangan dan arus keluaran inverter disebabkan oleh proses switching IGBT yang dipicu oleh sinyal kontrol dan kurang sesuainya nilai induktor yang digunakan. Nilai \%THD-i dengan menggunakan variasi beban $7 \Omega$ lebih besar dibandingkan menggunakan variasi $12 \Omega$. Hal ini dikarenakan tegangan yang mengalir pada beban lebih kecil. Pada pengujian dengan menggunakan kontroler proportional integral, perubahan variasi arus referensi tidak terlalu berdampak pada perubahan nilai \%THD-i. Sedangkan, \% THD-i akan semakin kecil ketika arus referensi yang diberikan semakin besar pada pengujian dengan kontroler proportional resonant. Pada kontroler proportional resonant yang dilengkapi dengan kontrol sinkronisasi tegangan, gelombang arus keluaran inverter yang dihasilkan lebih baik dan memiliki nilai \%THD-i yang lebih kecil dibandingkan dengan kontroler proportional resonant tanpa sinkronisasi tegangan. Sehingga, kontroler proportional resonant dengan sinkronisasi tegangan adalah kontroler yang paling baik untuk digunakan sebagai pengendalian arus AC.

\section{Referensi}

[1] F. Blaabjerg, R. Teodorescu, M. Liserre, and A. V Timbus, "Overview of control and grid synchronization for distributed power generation systems," IEEE Trans. Ind. Electron., vol. 53, no. 5, pp. 1398-1409, 2006.

[2] M, Shahidehpour, F Schwartz. Don't Let The Sun Go Down on PV. 2004.

[3] G. Shen, X. Zhu, J. Zhang, and D. Xu, "A new feedback method for PR current control of LCL-filter-based gridconnected inverter," IEEE Trans. Ind. Electron., vol. 57, no. 6, pp. 2033-2041, 2010.

[4] D. Zammit, C. S. Staines, and M. Apap, "Comparison between PI and PR Current Controllers in Grid Connected PV Inverters," vol. 8, no. 11, pp. 1591-1597, 2014

[5] Jahan, Syah, "Implementasi Kontrol Arus Pada Inverter Satu Fasa Menggunakan DSPIC30F4011 dengan Metode Kontrol Proportional Resonant," Transient.

[6] TOSHIBA, "TOSHIBA Photocoupler GaAlAs Ired \& Photo-IC TLP 250," vol. 5, pp. 1-8, 2007.

[7] S. Muttaqin, I. Setiawan, and M. Facta, "Desain dan Implementasi Voltage-Source Inverter ( VSI ) Tiga Fase Sinusoidal Pulse-Width Modulation (SPWM) dengan DSPIC30F4011," TRANSMISI, vol. 18, no. 4, 2016.

[8] D. Zammit, C. S. Staines, and M. Apap, "Comparison between PI and PR Current Controllers in Grid Connected PV Inverters," vol. 8, no. 11, pp. 1591-1597, 2014.

[9] N. Zhang, H. Tang, and C. Yao, “A Systematic Method for Designing a PR Controller and Active Damping of the LCL Filter for Single-Phase Grid-Connected PV Inverters," Energies, vol. 7, no. 6, pp. 3934-3954, 2014.

10] M Gopal, Digital control and state variable methods, 2nd ed. 